\title{
Anode Catalyst Development for Direct Formic Acid Fuel Cell
}

\author{
Aslam $\mathrm{MN}^{1}$, Abd Lah Halim $\mathrm{F}^{2}$ and Tsujiguchi $\mathrm{T}^{2 *}$ \\ ${ }^{1}$ Division of Mechanical Engineering, Japan \\ ${ }^{2}$ Faculty of Mechanical Engineering, Japan
}

ISSN: 2576-8840

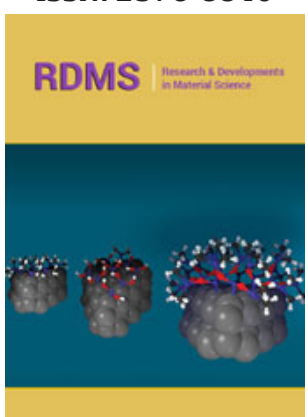

*Corresponding author: Takuya Tsujiguchi, Faculty of Mechanical Engineering, Institute of Science and Engineering, Kanazawa University, Japan

Submission: 酸 October 31, 2019

Published: 䌉 November 07, 2019

Volume 12 - Issue 2

How to cite this article: Aslam MN, Abd Lah Halim F, Tsujiguchi T. Res Dev Material Sci. 12(2).RDMS.000783.2019.

DOI: 10.31031/RDMS.2019.12.000783

Copyright@ Takuya Tsujiguchi, This article is distributed under the terms of the Creative Commons Attribution 4.0 International License, which permits unrestricted use and redistribution provided that the original author and source are credited.

\section{Abstract}

Extensive studies have been reported on improving the performance of direct formic acid fuel cell (DFAFC) including the catalyst layer in which the electrochemical reaction takes place. This review is focusing on the anode catalysts development to improve the electrocatalytic performance for formic acid oxidation reaction (FAOR) including the modification on the metal and support of the catalyst. These efforts are contributing in the enhancing the catalyst electrocatalytic performance and reducing the usage of high cost catalyst material which is beneficial for commercialization purpose.

Keywords: Formic acid oxidation reaction; Anode catalyst; Catalyst support

\section{Introduction}

Direct formic acid fuel cell (DFAFC) is one of the promising direct liquid fuel cell (DLFC) due to its capabilities of favorable oxidation kinetics enabling low operating temperatures $\left(50-80{ }^{\circ} \mathrm{C}\right)$, high theoretical open circuit voltage $(1.45 \mathrm{~V})$ and relatively low fuel crossover through Nafion membrane due to repulsion between HCOO- ions in formic acid and sulfuric group in Nafion membrane [1-3]. Basically, DFAFC uses formic acid to generate electricity without intermediate step such as reforming the alcohol into hydrogen. Liquid formic acid is easily found and approved by the US Food and Drug Administration (FDA) as a food additive. Formic acid electro-oxidation occurs via a dual reaction pathway that reduce the percentage of poisoning toward the surface as intermediate reaction [4]. Redox reaction of formic acid as shown in the Equation 1.1 for the anode and cathode reaction.

$$
\begin{aligned}
& \mathrm{HCOOH} \rightarrow[\mathrm{CO}]_{-} 2+[2 \mathrm{H}]^{\wedge}++2 e^{\wedge}(\text { anode }) \\
& {[2 \mathrm{H}]^{\wedge}++2 e^{\wedge}+1 / 2 O_{-} 2 \rightarrow H_{-} 2 \mathrm{O}(\text { cathode })} \\
& \mathrm{HCOOH}+1 / 2 O_{-} 2 \rightarrow \mathrm{CO}_{-} 2+H_{-} 2 \mathrm{O}\left(E^{\wedge} 0=1.45 \mathrm{~V}\right)
\end{aligned}
$$

Principally, DFAFCs are subcategory of polymer electrolyte membrane fuel cells (PEMFCs) in which formic acid as aqueous solution instead of hydrogen. At the anode, formic acid solution diffuses through the diffusion layer and the catalyst layer where solution is electrochemically oxidized into carbon dioxide $\left(\mathrm{CO}_{2}\right)$ and two electrons compared to direct methanol fuel cell (DMFC) which generates six electrons. This means that at a same current density, DFAFC requires two times amount of fuel [5]. Like most of other DLFCs, chemical used in DFAFCs also release $\mathrm{CO}_{2}$ in the reaction which is not completely safe and not emission-free. However, $\mathrm{CO}_{2}$ can be converted into various valuable chemicals such as formic acid through electrochemical reduction and can be reused in DFAFC [6]. The $\mathrm{CO}_{2}$ generated from the oxidation reactions emerges from the anode backing layer as bubbles and is removed via the flowing aqueous formic acid solution. Protons formed during this reaction diffuse through the electrolyte membrane to the cathode layer. Likewise, in the DMFC, electrons and protons combine with oxygen to form water at cathode. As the components of DFAFC are similar to the DMFC, except for the anode catalyst, development of anode catalyst for DFAFCs have drawn considerably attention by many researchers. Hence, the objective of this paper is to review the anode catalysts development to improve the electrocatalytic performance for formic acid oxidation reaction (FAOR) including the modification on the metal and support of the catalyst.

\section{Anode catalyst development}

In DFAFC operation, palladium- (Pd) or platinum- (Pt) based catalysts are the most utilized as the anode catalyst for formic acid oxidation reaction (FAOR) but, Pd-based is 
regarded as more active than Pt-based. This is due to the less carbon monoxide (CO) poisoning on the Pd than Pt. Formic acid electrooxidation on Pd-based catalyst usually proceeds on a direct pathway (dehydrogenation) in which formic acid is oxidized to $\mathrm{CO}_{2}$ without forming CO [7]. FAOR on a Pt-based catalyst follows the socalled dual pathways of dehydrogenation and the indirect reaction pathway that forms adsorbed $\mathrm{CO}$ as an intermediate reaction. This intermediate reaction will lead to $\mathrm{Pt}$ poisoning by $\mathrm{CO}$ and reduce its electrocatalytic performance [8]. Pt-based catalysts have been widely developed to improve the electrocatalytic performance [9]. The application of bimetallic alloys such as Pt-Ru, Pt-Pd, Pt-Au, Pt$\mathrm{Bi}$ [10-12] was found to exhibit better electrocatalytic activity than the pure noble metals for FAOR. In a study done by C. Rice et al., the behavior of Pt black, Pt-Ru and Pt-Pd catalyst under a real fuel cell operation was reported. It was concluded that the addition of Pd to the Pt catalyst improves the formic acid electrooxidation rate via direct reaction pathway whereas addition of $\mathrm{Ru}$ to the Pt enhances the electrooxidation via indirect reaction pathway that forming $\mathrm{CO}$ intermediates [10].

A recent study done by Choi et al. [13] to improve the FAOR of the Pt-based catalyst is by using a simple and easy method to prepare $\mathrm{Bi}$-modified $\mathrm{Pt} / \mathrm{C}$ catalyst in which the $\mathrm{Bi}$ was reversibly adsorbed on a commercial Pt/C catalyst. The Bi-modified Pt/C catalyst demonstrates an excellent FAOR activity as compared with the non-modified $\mathrm{Pt} / \mathrm{C}$ catalyst. Further, single-cell performance was improved using the Bi-modified $\mathrm{Pt} / \mathrm{C}$ as the anode catalyst with a power density of over 2.5 times that of the commercial Pt/C and Pt black anode catalyst. In addition, they also successfully manufactured a DFAFC stack that delivered $300 \mathrm{~W}$ power by employing the Bi-modified $\mathrm{Pt} / \mathrm{C}$ at the cathode which is expected to contribute to the commercialization of DFAFC [13]. To date, extensive studies are also reported on Pd-based catalyst for formic acid electro-oxidation due to its high anti-poisoning ability than Pt-based catalyst. However, a major problem of Pd-based catalysts is their poor electrocatalytic stability. Alloying the Pd with other metal ( $\mathrm{Ni}, \mathrm{Zn}, \mathrm{V}, \mathrm{Au}, \mathrm{Co})$ or element is one of the efforts to improve the electrocatalytic activity and stability. Carbon supported Pd-Ni (Pd-Ni/C) catalyst was found to be better in the electrocatalytic activity and stability than the $\mathrm{Pd} / \mathrm{C}$ catalyst due to the decrease in the decomposition of formic acid as shown in the study done by Shen et al. [14].

From the recorded volume of gas produced from the formic acid decomposition over the catalyst, it was found that gas volume produced for the $\mathrm{Pd}-\mathrm{Ni} / \mathrm{C}$ catalyst are much less than that of $\mathrm{Pd} / \mathrm{C}$ catalyst. This finding indicates that $\mathrm{Pd}-\mathrm{Ni} / \mathrm{C}$ catalyst can fully prevent the formic acid decomposition and reduce the CO production which contribute in the improved electrocatalytic activity and stability of the Pd-Ni/C catalyst for FAOR [14]. Similar trend obtained by Fathirad [15] in which the electrocatalytic activity and stability of carbon supported Pd-Zn (Pd-Zn/C) catalyst is better than Pd/C catalyst. They also proved that the different atomic ratio affects the formic acid electrooxidation and stability of a Pd-Zn/C catalyst. The electroactivity increases as the $\mathrm{Pd} / \mathrm{Zn}$ atomic ratio increases up to 65.2:34.8 (Pd2Zn/C). Further increase in the metal atomic ratio results in decrease of the electroactivity of the $\mathrm{Pd}-\mathrm{Zn} / \mathrm{C}$ catalyst. It was reported that the $\mathrm{Pd} 2 \mathrm{Zn} / \mathrm{C}$ catalyst has the smallest average crystallite size $(8.2 \mathrm{~nm})$ and largest electrochemical surface area. [15]. Another factor that was proved to affect the electrocatalytic activity and stability of Pd-based alloy catalyst is the alloying degree. Carbon supported Pd-Au (Pd-Au/C) catalyst with high and low alloying degree prepared by the co-reduction of Pd and Au salt precursor in aqueous solution with or without tetrahydrofuran (THF) in the study reported by Zhang et al. [16] High alloy degree $\mathrm{Pd}-\mathrm{Au} / \mathrm{C}$ catalyst shows a higher activity and stability for FAOR than that low alloying degree catalyst. This is because the high alloying degree catalyst has better CO tolerance and possible suppression of dehydration pathway for formic acid electrooxidation [16].

Different second metal added to the Pd-based catalyst also affects the FAOR activity and stability and the single DFAFC performance. Caglar et al. [17] synthesized and characterized carbon nanotube (CNT) supported Pd-Co, Pd-V, Pd-Mn and Pd-Zn catalysts for formic acid electrooxidation activity and stability. Pd-Co/CNT catalyst exhibited the best activity and stability than the other catalysts including the Pd/CNT catalyst [17]. Instead of alloying Pd with other metals, Zhang et al. [18] prepared a highly active and stable Pd hydride ( $\mathrm{PdHx}$ ) catalyst by simply treating a commercial Pd black with n-butylamine in solvothermal condition. As compared with the untreated commercial Pd black catalyst, the PdH catalyst exhibited a very low peak potential, a high mass activity and greater catalytic stability towards the formic acid electrooxidation. In addition, the preparation method used can be regarded as facile and cost-effective which is suitable for practical application [18]. Table 1 shows the summary of electrocatalytic performance of current studies on the Pd-based catalyst for FAOR. From the literatures discussed here, it can be concluded that addition of second metal or element to the $\mathrm{Pd} / \mathrm{C}$ catalyst can successfully improve the electrocatalytic activity and stability for FAOR.

Table 1: Electrocatalytic activity result of Pd-based catalyst for FAOR.

\begin{tabular}{|c|c|c|c|}
\hline Reference & Catalyst & $\begin{array}{c}\text { Anodic Peak } \\
\text { Potential (mV) }\end{array}$ & $\begin{array}{c}\text { Peak Current } \\
\text { Density } \\
\text { (mA cm } \mathbf{~ c m}^{-2}\end{array}$ \\
\hline Zhang et al. [16] & $\begin{array}{c}\mathrm{Pd}-\mathrm{Au} / \mathrm{C} \\
\mathrm{Pd} / \mathrm{C}\end{array}$ & 15 & 19 \\
\hline \multirow{2}{*}{ Shen et al. [14] } & $\mathrm{Pd}-\mathrm{Ni} / \mathrm{C}$ & 22 & 12.4 \\
\hline \multirow{2}{*}{ Fathirad [15] } & $\mathrm{Pd} / \mathrm{C}$ & 12 & 19.3 \\
& $\mathrm{Pd}-\mathrm{Pn} / \mathrm{C}$ & $\sim 30$ & 0.95 \\
\hline \multirow{2}{*}{ Zhang et al. [18] } & $\mathrm{PdH}$ & $\sim 35$ & $\sim 9$ \\
& $\mathrm{Pd}$ black & 22 & 5.12 \\
& $\mathrm{Pd}-\mathrm{Co} /$ & $200-400$ & 6.89 \\
\hline \multirow{2}{*}{ Caglar et al. [7] } & $\mathrm{CNT}$ & - & 0.68 \\
& $\mathrm{Pd} / \mathrm{CNT}$ & & \\
\hline
\end{tabular}


Besides alloying the Pd-based catalyst with the other non-noble metal or other element, the electrocatalytic performance toward the FAOR can be improved by development of catalyst support structure. Supported catalyst can reduce the usage of expensive metal catalyst simultaneously improving the catalyst electroactivity $[19,20]$. Desired supported catalysts are expected to have high surface area, good electrical conductivity, electrochemical stability and suitable porosity shows good stability, good interaction as a catalyst support, the ability to repel water and prevent flooding, corrosion resistance, easily restore catalyst function and higher activity than unsupported catalyst [20-25]. Unsupported catalysts suffer aggregation and surface area degradation during catalytic reaction took place [26], however the investigation of unsupported catalyst could provide the understanding on the catalytic activity on specific catalyst [27].

Support material have been roughly classified as carbon-based support and non-carbon-based support [20]. Among non-carbonbased material that attract researchers attention were titania [28-31], alumina, silica [28], ceria [30], zirconia, tungsten oxide and conducting polymers [20]. Non-carbon support improved the reaction kinetics due to the metal-support interaction, however, their electrical conductivity was lower than that of the carbon support. The lower electrical conductivity should be improved when non-carbon support is used as catalyst support, and this was pointed out by Ito et al. [29] \& Kunitomo et al. [30]. In their studies, the non-carbon supported PtRu catalyst, such as ceria particles [30] and titania particles [29], gave lower performance for methanol oxidation comparing to the carbon support.

Carbon based support such as carbon blacks (CBs) such as Vulcan XC-72, Ketjen black, etc., [22] and novel nanostructured carbon such as carbon nanotube (CNT) [7,32-34], carbon nanofiber (CNF), carbon microbeads and carbon nanocoils [35] graphene [26] and mesoporous carbon [20,36] are widely used in low temperature fuel cells. Nanostructured carbon support seems to enhance catalyst activity due to its high surface areas which increases reaction surface areas of catalyst [37]. Carbon based material is favored as catalyst support due to its properties of high electrical conductivity, corrosion resistance, porous structure and specific surface area. These properties are differ based on the carbon materials. Usually high specific surface area is needed to serve high dispersion of catalyst particles; however, high specific surface area only is inadequate as efficient catalyst support. Pore properties such as pore size and distribution and surface chemistry are also important to take into account [38]. Carbon nanostructure not only reduce the cost of fuel cell operation by reducing the catalyst loading but also contributed to high performance due to catalytic reaction occurred at the active sites [39].

\section{Conclusion}

In summary, the electrocatalytic performance improvement of anode catalyst for formic acid oxidation reaction (FAOR) can be realized either on the metal (Pt or Pd) or the support material. Addition of second metal or element to the Pt- or Pd-based catalysts was found to enhance the electro-oxidation of formic acid and stability of the catalysts. This is due to the increase the ability of the catalyst to proceed in the direct reaction pathway and CO tolerance. Further, the modification on the catalyst support material also leads in the change of physical properties and the metal support interaction which contribute in improving the electrocatalytic performance.

\section{References}

1. Hong P, Liao S, Zeng J, Huang X (2010) Design, fabrication and performance evaluation of a miniature air breathing direct formic acid fuel cell based on printed circuit board technology. J Power Sources 195(21): 7332-7337.

2. Rees NV, Compton RG (2011) Sustainable energy: a review of formic acid electrochemical fuel cells. J Solid State Electrochem 15(10): 2095-2100.

3. Aslam NM, Masdar MS, Kamarudin SK, Daud WRW (2012) Overview on direct formic acid fuel cells (dfafcs) as an energy sources. APCBEE Procedia 3: 33-39.

4. Rice C, Ha S, Masel RI, Waszczuk P, Wieckowski A, et al. (2002) Direct formic acid fuel cells. J Power Sources 111(1): 83-89.

5. Cai W, Liang L, Zhang Y, Xing W, Liu C (2012) Real contribution of formic acid in direct formic acid fuel cell : Investigation of origin and guiding for micro structure design. Int J Hydrogen Energy 38(1): 212-218.

6. Wu H, Song J, Xie C, Hu Y, Han B (2018) Highly efficient electrochemical reduction of $\mathrm{CO}_{2}$ into formic acid over lead dioxide in an ionic liquidcatholyte mixture. Green Chem 20(8): 1765-1769.

7. Caglar A, Sahan T, Cogenli MS, Yurtcan AB, Aktas N, et al. (2018) A novel central composite design based response surface methodology optimization study for the synthesis of $\mathrm{pd} / \mathrm{cnt}$ direct formic acid fuel cell anode catalyst. Int J Hydrogen Energy 43(24): 11002-11011.

8. Ren F, Zhou W, Du Y, Yang P, Wang C, et al. (2011) High efficient electrocatalytic oxidation of formic acid at Pt dispersed on porous poly(o-methoxyaniline). Int J Hydrogen Energy 36(11): 6414-6421.

9. Uhm S, Lee HJ, Lee J (2009) Understanding underlying processes in formic acid fuel cells. Physical chemistry chemical physics 11(41): 93269336.

10. Rice C, Ha S, Masel RI, Wieckowski A (2003) Catalysts for direct formic acid fuel cells. J Power Sources 115(2): 229-235.

11. Peng Z, Yang H (2009) PtAu bimetallic heteronanostructures made by post-synthesis modifi cation of pt-on-au nanoparticles. Nano Res 2(5): 406-415.

12. Uhm S, Lee HJ, Kwon Y, Lee J (2008) A stable and cost-effective anode catalyst structure for formic acid fuel cells. Angew Chemie-Int Ed 47(52): 10163-10166.

13. Choi M, Ahn CY, Lee H, Kim JK, Oh HS, et al. (2019) Bi-modified Pt supported on carbon black as electro-oxidation catalyst for $300 \mathrm{~W}$ formic acid fuel cell stack. Appl Catal B Environ 253: 187-195.

14. Shen L, Li H, Lu L, Luo Y, Tang Y, et al. (2013) Improvement and mechanism of electrocatalytic performance of $\mathrm{Pd}-\mathrm{Ni} / \mathrm{C}$ anodic catalyst in direct formic acid fuel cell. Electrochim Acta 89: 497-502.

15. Fathirad F, Afzali D, Mostafavi A (2016) Bimetallic Pd-Zn nanoalloys supported on vulcan XC-72R carbon as anode catalysts for oxidation process in formic acid fuel cell. Int J Hydrogen Energy 41(30): 1322013226.

16. Zhang G, Wang Y, Wang X, Chen Y, Zhou Y, et al. (2011) Preparation of Pd$\mathrm{Au} / \mathrm{C}$ catalysts with different alloying degree and their electrocatalytic performance for formic acid oxidation. Appl Catal B Environ 102(3-4): 614-619.

17. Caglar A, Ulas B, Cogenli MS, Yurtcan AB, Kivrak H (2019) Synthesis and characterization of $\mathrm{Co}, \mathrm{Zn}, \mathrm{Mn}, \mathrm{V}$ modified Pd formic acid fuel cell anode catalysts. J Electroanal Chem 850: 113402. 
18. Zhang J, Chen M, Li H, Li Y, Ye J, et al. (2018) Stable palladium hydride as a superior anode electrocatalyst for direct formic acid fuel cells. Nano Energy 44: 127-134.

19. Wang YJ, Wilkinson DP, Zhang J (2011) Noncarbon support materials for polymer electrolyte membrane fuel cell electrocatalysts. Chem Rev 111(12): 7625-7651.

20. Sharma S, Pollet BG (2012) Support materials for PEMFC and DMFC electrocatalysts-A review. J Power Sources 208: 96-119.

21. Bianchini C, Shen PK (2009) Palladium-based electrocatalysts for alcohol oxidation in half cells and in direct alcohol fuel cells. Chem Rev 109(9): 4183-4206.

22. Holade Y, Morais C, Servat K, Napporn TW, Kokoh KB (2014) Enhancing the available specific surface area of carbon supports to boost the electroactivity of nanostructured Pt catalysts. Phys Chem Chem Phys 16(46): 25609-25620.

23. Chang J, Li S, Feng L, Qin X, Shao G (2014) Effect of carbon material on Pd catalyst for formic acid electrooxidation reaction. J Power Sources 266: 481-487.

24. Majlan EH, Rohendi D, Daud WRW, Husaini T, Haque MA (2018) Electrode for proton exchange membrane fuel cells: A review. Renew Sustain Energy Rev 89: 117-134.

25. Yu X, Pickup PG (2008) Recent advances in direct formic acid fuel cells (DFAFC). J Power Sources 182(1): 124-132.

26. Zhang Z, Gong Y, Wu D, Li Z, Li Q et al. (2019) Facile fabrication of stable PdCu clusters uniformly decorated on graphene as an efficient electrocatalyst for formic acid oxidation. Int J Hydrogen Energy 44(5): 2731-2740

27. Gralec B, Lewera A (2016) Catalytic activity of unsupported Pd-Pt nanoalloys with low Pt content towards formic acid oxidation. Appl Catal B Environ 192: 304-310.

28. Onishi R, Tsujiguchi T, Osaka Y, Kodama A (2015) High formic acid oxidation activity and stability of pd catalyst supported by nanoparticleembedded carbon nanofiber. ECS Trans 69(17): 663-674.

29. Ito Y, Takeuchi T, Tsujiguchi T, Abdelkareem MA, Nakagawa N (2013) Ultrahigh methanol electro-oxidation activity of PtRu nanoparticles prepared on Ti0 2 -embedded carbon nano fi ber support. J Power Sources 242: 280-288.

30. Kunitomo $\mathrm{H}$, Ishitobi $\mathrm{H}$, Nakagawa $\mathrm{N}$ (2015) Optimized $\mathrm{CeO}_{2}$ content of the carbon nanofiber support of PtRu catalyst for direct methanol fuel cells. J Power Sources 297: 400-407.

31. Tsujiguchi T, Aslam NM, Onishi R, Osaka Y, Kodama A, et al. (2016) Power generation characteristics of the direct formic acid fuel cell using silica containing carbon nanofiber as the anode supports. ECS Trans 75(14): 997-1004

32. Cui Z, Kulesza PJ, Ming C, Xing W, Ping S (2011) Pd nanoparticles supported on HPMo-PDDA-MWCNT and their activity for formic acid oxidation reaction of fuel cells. Int J Hydrogen Energy 36(14): 85088517.

33. Morales-acosta D, Morales-acosta MD, Godinez LA, Álvarez-contreras L, Duron-torres SM, et al. (2011) PdCo supported on multiwalled carbon nanotubes as an anode catalyst in a microfluidic formic acid fuel cell. J Power Sources 196(22): 9270-9275.

34. Selvaraj V, Grace AN, Alagar M (2009) Electrocatalytic oxidation of formic acid and formaldehyde on nanoparticle decorated single walled carbon nanotubes. J Colloid Interface Sci 333(1): 254-262.

35. Fang B, Kim M, Yu J-S (2008) Hollow core/mesoporous shell carbon as a highly efficient catalyst support in direct formic acid fuel cell. Appl Catal B Environ 84(1-2): 100-105.

36. Shao Y, Liu J, Wang Y, Lin Y (2009) Novel catalyst support materials for PEMfuelcells: current status and future prospects. J Mater Chem 19(1): 46-59.

37. Antolini E (2009) Carbon supports for low-temperature fuel cell catalysts. Appl Catal B Environ 88(1-2): 1-24.

38. Lázaro MJ, Calvillo L, Celorrio V, Moliner R (2011) Study and application of Vulcan XC-72 in low temperature fuel cells. Carbon Black Prod Prop Uses. Nova science publishers, USA, pp: 41-68.

39. Zhang XJ, Zhang JM, Zhang PY, Li Y, Xiang S, et al. (2017) Highly active carbon nanotube-supported Ru@Pd core-shell nanostructure as an efficient electrocatalyst toward ethanol and formic acid oxidation. Mol Catal 436: 138-144.

For possible submissions Click below: 